\title{
School Management from the Perspective of Social Transformations at Work
}

\author{
Mauricio Bueno da Rosa ${ }^{1}$, Eliane Griep Gomes Bitencourt ${ }^{2}$, Muhammad Ridwan ${ }^{3}$ \\ ${ }^{I}$ Federal University of Santa Catarina, Brazil \\ ${ }^{2}$ Federal University of Paraná, Brazil \\ ${ }^{3}$ Universitas Islam Negeri Sumatera Utara, Indonesia \\ Mauriciobueno7@hotmail.com, elianegriep@hotmail.com, bukharyahmedal@gmail.com
}

\begin{abstract}
In this article we intend to address the context of the school routine that is governed by rules developed by the sectors responsible for school management. In the bureaucratization of school work we see the same meaning and dimensions as the bureaucratization of other sectors of production. As the training of the workforce was transferred to the school, this institution incorporated in its organization and functioning new elements and fundamental characteristics to achieve a good performance as a socializing agency for the worker. On the other hand, the figure of the autonomous teacher, of the humanist, encyclopedist type, has also disappeared. Whether in public education or in the private network, the vast majority of teachers are in the condition of salaried workers. In this way, the process of proletarianization of teaching workers is characterized, characterized by their working conditions. The division of school work, as it developed based on the same principles as the so-called management theories, reinforces the reproduction of capitalist logic in school pedagogical practice because new practices and relationships are crystallized in this practice.
\end{abstract}

Keywords society, schod; management; autonomy

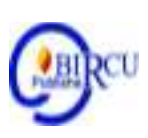

\section{Introduction}

When entering the school pedagogical practice, it appears that in recent years, education specialists, in the role of teaching managers, have played a prominent role. They have been assigned the tasks of directing, planning, supervising and controlling the school's pedagogical and administrative process. The rest of the teaching workers are given the tasks of carrying out the work previously planned. In this way, we see the growing centralization and hierarchy of work processes at school.

Concomitant with this process of hierarchization and centralization of pedagogical work, its bureaucratization also develops, when general, impersonal and comprehensive rules that characterize bureaucracy are implemented in pedagogical practice today. The school routine is governed by rules developed by the sectors responsible for school management, which contribute little to the dynamization of pedagogical practice. On the contrary, all of this contributes to the performance of education professionals to drown in the tangle of laws, plans and records, which are often drawn up only to meet those standards. According to Russo (2016, p. 197) In the daily practice of our schools, planning has been a bureaucratic and meaningless task, often representing just one more document for the coordinator's file. It is the separation between thinking and doing, according to the logic of the system. Teachers participate little or nothing in the conception and elaboration of the work processes that they will develop with their students. Following the logic of the 
system, the division of labor consists of groups that plan and groups that execute. Coordinators are given the task of planning and controlling the teaching process; teachers have the task of carrying out what was planned.

In the bureaucratization of school work we see the same meaning and dimensions as the bureaucratization of other sectors of production. In other words, a mechanism of centralization of power that consolidates the group of teaching managers, specialist technicians, thus deepening the dichotomy between who controls and who performs the pedagogical work. In this context of social relations, the rationalization of school work, based on capitalist logic, has been decisive for teachers and students to lose control of the educational process in which they are (or should be) the main protagonists.

As the training of the workforce was transferred to the school, this institution incorporated in its organization and functioning new elements and fundamental characteristics to achieve a good performance as a socializing agency for the worker. Education workers, in turn, have lost control of the school work process, at the same time that the definition of the direction of school educational practice has become the responsibility of education managers. The teacher was being curtailed in his autonomy.

\section{Research Methods}

We use bibliographic research as a methodological procedure, seeking to base itself on the texts on the reality of pedagogical management, which are fundamental considerations for the conceptual delimitation of the theme.

We will follow an argumentative line as to the concepts worked on, using the method of qualitative research, addressing historical and sociological aspects of education and its scope as to the concept of childhood that can be understood from the understanding of pedagogical practice and teaching work.

The locus of the research will be the basic school specifically in the segment of daily education, where we did the data collection using the research by observation, through seeing, hearing and examining facts or phenomena. Thus, the research that resulted in this article was systematically planned, methodically registered and subject to control checks.

\section{Results and Discussion}

In the context of controlling actions, we can see that the figure of the autonomous teacher, of the humanist, encyclopedist type, has disappeared. Whether in public education or in the private network, the vast majority of teachers are in the condition of salaried workers, whose basic function is to master a portion of school knowledge to transmit it to the student. For Matins (2011, p. 34)

Urbanization, the introduction of complete and serial schools, school concentrations, the expansion of the public sector, the creation of private schools for sectors with high purchasing power and its generalization for all with the subsidy policy, are the factors that have made it disappear. the autonomous teacher, including the semi-autonomous public master in the countryside. The creation and then the absolute predominance of schools with several school groups supposed the division and hierarchy of teachers, with the appearance 
of the figure of the principal and other intermediaries. The figure of the principal has its correlate in a certain loss of autonomy on the part of the basic teacher. ${ }^{1}$

In this way, the process of proletarianization of teaching workers is outlined, characterized, on the one hand, by their working conditions that are increasingly identified with those of other sectors of production, such as the prolonged one. working hours, the process of alienation and disqualification of their activity, the bureaucratic structure of their workplace - the scale, the difficult professional conditions and the low wages. On the other hand, the proletarianization of teaching workers is outlined, due to the very real approach of these workers to the other proletarians in their process of organization and struggle, because "the organization of educational work on a business basis led the orderly public teachers to feel they were not public servants, but labor power sold to a boss called the state. ${ }^{2}$

Thus, the rational organization of pedagogical work, by emphasizing the bureaucratization of school management and placing planning and execution of the educational process in different hands, contributed to the teacher losing control and control of the work he does and, at the same time, time, if subordinated to the interests of capital.

The introduction and deepening of the technical division of school work, the expropriation of the means of production and transmission of school knowledge, the wage regime based on the squeeze, and the large private and state educational companies, but definitely in check the conception and practice of said school traditional (...) The result of this transformation process was the proletarianization of education work- Regardless of whether they were teachers or technicians, public and private workers, they were all expropriated from their means of production and reproduction. They have nothing but their labor power like any proletarian (SÁ, 1986, p. 87).

The division of school work, when developed based on the same principles of the socalled administration theories, reinforces the reproduction of the capitalist logic in school pedagogical practice because new practices and relationships are crystallized in this practice. Therefore, in this process we see the deepening of capitalist relations in the organization of school work and, consequently, the consolidation of the proletarianization of teaching workers.

These transformations in the school work process, however, do not happen for free. Explaining them as a natural result of the complexification that the school has undergone, as a result of new organizational forms and new technologies incorporated into the pedagogical routine, actually means incurring the mistake of placing science and technology, including educational technology, outside the historical conditions in which they are produced. According to this way of conceiving and carrying out education, the serious and complex problems that manifest themselves at an educational level are reduced to the condition of purely technical problems, leaving the so-called education specialists to solve them and present the best way to solve them. them. The technicians in education appear, then, as those who really understand the subject, have the knowledge of education, truly enlightened, holders of scientific knowledge that is, rigorous, objective and neutral in the educational process. It is the social division of labor, also manifesting itself in the field of education as a natural rational.

\footnotetext{
${ }^{1}$ To expand this discussion we suggest reading the article Implementation of Playing Methods in Learning Science in Improving Children's Critical Thinking Ability in Raudhatul Athfal Assyifa Medan (2020) written by Tien Rafida1, Mariani Harahap.

${ }^{2}$ it is important to quote the article Analysis the Role of Headmaster in ApplyingQuality of Education in Primary School Districts, Aceh Barat (2019) written by Musdiani, Mardhatillah and Khausar where we can understand other aspects of this discussion.
} 
In fact, the way in which the work process is organized has a much greater significance than simply a natural result of the school's complexification, because, on the one hand, through this organization the deepening of capitalist relations within the school will develop and, on the other, because this organization is, above all, educational. Now, the school educates not only for the content it transmits, but mainly for the way it organizes the educational practice in which this transmission occurs. Even though it is progressive in its content, your organization may be contributing to fulfill another function, which meets the interests of capital. Thus, by incorporating in its organization and functioning the same principles that support the other fields of capitalist production, its function as a training and socializing agency for the workforce is reinforced. The school is linked to the company due to the socializing function it exercises over the future workforce. Socializing function that is not only exercised, nor fundamentally, by the contents it transmits, but above all by the structure and organization that the school embodies. The introduction of mechanisms and practices that predominate in the business organization will make the school structure a socializing agent insofar as it reproduces, in its organization, the model of society that the student will have to adapt to when entering the job market.

On the other hand, in this organization of pedagogical work, the separation between planners and executors of school work, in addition to meaning the deepening of capitalist logic within the school, explains an understanding of the relationship between theory and practice, in which the first is conceived as the foundation and second guide. The relationship between theory and practice thought in this way makes knowledge, science appear as something given, ready, finished, perceiving knowledge and its production process. In the history of thought, this is the case with idealistic, positivist, a-historical conceptions, which isolate the process of producing knowledge from the social totality that permeates it, over-structuring it.

In opposition to these conceptions, it has already been shown that knowledge must be conceived as something socially produced, in the relationships that individuals establish with each other and with nature, in the material production of their existence, because knowledge is constructed and developed from human, historically and socially determined needs. Knowledge is not a mere abstraction, a simple set of laws and categories, unhistorical, free from the desires and aspirations of individuals. The knowledge construction process is, above all, a social, collective, historical process, and, therefore, subject and the abject of this process, or even knowledge itself, cannot be situated as metaphysical entities, above the real, immune to the historical and social determinations in which they are located. ${ }^{3}$

In this perspective, the relationship between theory and practice cannot be thought of as a mechanical, unidirectional relationship, in which, on the one hand, there is the cause and, on the other, the effect; on the one hand the seed, the essence, and on the other, the fruit, the existence. On the contrary, this relationship is, above all, a relationship of mutual determination, of procedural interdependence, because its two poles make up the movement of the real, of social transformations, of the objective existence of individuals

In this context, the conditions for the precariousness of teaching methods and processes to take place are consolidated, insofar as, on the one hand, educational problems start to be explained as resulting from an inadequate use of technical-methodological resources and, on the other hand, the division, hierarchization and bureaucratization of

\footnotetext{
${ }^{3}$ It is important to highlight the article Assessment of the Quality of Life, Health, and Social Wellness in Upper Elementary School Students: Cross-Cultural and Gender Specificity (2020).
} 
school work are conceived as a natural phenomenon in modern society, so it is natural that this same phenomenon happens in the school work process. Indeed, educational technology must also be understood in the context of the historical conditions in which it is formulated and used. And the emphasis on the methodological aspect of the teaching process is closely linked to the fragmentation of school work, based on the specialization of functions, in view of the obsessive career for the rationalization and efficiency of schools, strengthening teaching managers. This time, the precariousness of teaching methods and processes ends up constituting another mechanism for teaching workers to be prevented from participating in the management of their workplace, the school.

\section{Conclusion}

In turn, those who see theory as a guide for action in the educational process end up placing the axis of transmission-assimilation of knowledge as the core of pedagogical action within the school. In fact, the different pedagogical theories in general have revolved around how and what to teach, in order to ensure an adequate instrumentation of the individual to face social demands. Although progressive conceptions of coping with social demands are different, so-called progressive pedagogies continue to focus on the problem of the distribution-socialization of knowledge. The core of the pedagogical action remains, therefore, the same. The school educational process remains, therefore, focused on the question of how to teach something (content) efficiently (method) to someone (student). Therefore, it is believed that the guarantee of greater efficiency in school work resides in a rational organization of the teaching process that makes it possible to compensate and correct the teacher's deficiencies, maximizing the effects of his intervention. In this way, the center of the process moves to means, while professors and students start to occupy the position of performers of tasks.

\section{References}

Althusser, L. Aparelhos ideológicos do Estado. Rio de Janeiro: Graal, 2007.

Bernardo, J. Gestores, Estado e Capitalismo de Estado. São Paulo: Ensaio, 1985.

Marx crítico de Marx. Porto: Afrontamento, 1977. DOURADO, L.F. et al. Gestão Escolar Democrática. Goiânia: Editora Alternativa, 2003.

Belle, Helena Beatriz de Moura. Escola democrática e escola com burocracia atuação dos colégios da polícia militar no esta-do de Goiás. SABERES, Natal - RN, v. 2, n.esp, jun. 2011. Disponível em: <http://www.periodicos.ufrn.br/ojs/index.php/saberes/index>.

Brasil. Constituição da República Federativa do Brasil. De 05 de outubro de 1988.

Brzezinski, Iria. Gestão democrática, participativa, colegiada: concepção da disciplina gestão educacional no programa de pós-graduação em educação da UCG. Goiânia: 2007.

Costa, Jorge Adelino. Imagens organizacionais da escola. Edições ASA: Lisboa, 1996.

Dewey, John. Democracia e educação. Trad. de Godofredo Rangel e Anísio Teixeira. São Paulo: Companhia Editora Nacional,1959.

Freitag, B. Escola, Estado e Sociedade. São Paulo: Moraes, 1986. MORGAN, G. Imagens da Organização. São Paulo: Atlas, 2010.

Martins, Ângela Maria. Gestão e autonomia escolar: um estudo comparado Brasil/Portugal. Rev. Bras. Educ. [online]. 2011, vol.16, n.46 [cited 2020-12-06], pp.69-98. Available from: <http://www.scielo.br/scielo.php?script=sci_arttext\&pid=S1413- 
$24782011000100005 \& \operatorname{lng}=$ en\&nrm=iso $>$.

https://doi.org/10.1590/S1413-24782011000100005.

Musdiani; Mardhatillah; Khausar. Analysis the Role of Headmaster in Applying Quality of Education in Primary School Districts, Aceh Barat, Budapest International Research and Critics in Linguistics and Education (BirLE) Journal. Vol 2, n 3, August 2019, Page: 27-35.

Motta, F.C.P. Organização \& Poder: empresa, estado e escola. São Paulo: Atlas, 1990. O que é Burocracia. São Paulo: Brasiliense, 2000.

. Teoria das Organizações. São Paulo: Pioneira, 2003.

; Pereira, L.C.B. Introdução à Organização Burocrática. São Paulo: Pioneira, 2004.

Paro, Vitor H. Administração escolar: introdução crítica. São Paulo: Cortez: Autores Associados, 1986.

Popovic, Ružena; Samouilidou, Evdokia; Popović, Jasna; Dolga, Milan. Assessment of the Quality of Life, Health, and Social Wellness in Upper Elementary School Students: Cross-Cultural and Gender Specificity. Britain International of Humanties and Social Sciences (BIoHS) Journal. Vol. 2, n. 1, February 2020, Page: 127-142.

Rafida, Tien. Harahap, Mariani. Implementation of Playing Methods in Learning Science in Improving Children's Critical Thinking Ability in Raudhatul Athfal Assyifa Medan. Budapest International Research and Critics Institute-Journal (BIRCI-Journal) vol 3, n 2, May 2020, Page: 868-875.

Romeu, Sonia A. Escola: objetivos organizacionais e objetivos educacionais. São Paulo: EPU, 1987.

Russo, Miguel H. Teoria e prática da administração escolar: confluências e divergências. 1995. (311 p.) Tese (Doutorado em Educação) - Universidade de São Paulo, 1995.

SÁ, Nicanor Palhares. O aprofundamento das relações capitalistas no interior da escola. In: Cadernos de Pesquisa, n 56, v 20, maio. São Paulo, 1986.

Shaw, C.K.Y. Teoria Hegeliana da burocracia moderna. Fundação João Pinheiro, Belo Horizonte, vol. 7, n 1, jan/abr 1992.

Tragtenberg, M. "A Escola enquanto Organização Complexa". In: GARCIA, W. E. Educação Brasileira Contemporânea: organização e funcionamento. São Paulo: McGraw-Hill, 1981, p. 15-30. WEBER, M. Economia e Sociedade. Brasília: UnB, 1994. 